Rafał Dubowski

\title{
Ocena petycji w sprawie zniesienia instytucji ubezwłasnowolnienia'
}

\author{
Evaluation of a petition regarding the abolition of the institution \\ of incapacitation
}

\begin{abstract}
The petition under review concerns the proposal to abolish the institution of total and partial incapacitation, to introduce the institution of assistant care and the care with a concurrent representation. In the opinion of the author, the reform of the institution of legal incapacitation is required to fulfil international obligations. However, the solution proposed in the petition may insufficiently protect the interests of the protected person, his/her family, relatives and other legal entities. The author suggests that in some cases legislation should enable the possibility to apply substitution measures and, moreover, it is worth to consider introducing a mandatory periodic verification of the existence of the reasons for the use of a guardianship measure, in case of commencing activities on amending the relevant provisions.
\end{abstract}

Keywords: petition, legal incapacitation

W ocenianej petycji zaproponowano zniesienie instytucji ubezwłasnowolnienia całkowitego i częściowego, wprowadzenie instytucji opieki asystencyjnej oraz opieki z reprezentacją równoległą. Zdaniem autora opinii reforma instytucji ubezwłasnowolnienia jest pożądana ze względu na potrzebę wypełnienia zobowiązań międzynarodowych. Jednak proponowane w petycji rozwiązanie może niedostatecznie chronić interesy osoby objętej opieką, jej rodziny, bliskich oraz innych uczestników obrotu prawnego. Jego zdaniem w niektórych przypadkach - oprócz tych środków - ustawodawstwo powinno przewidywać możliwość zastosowania środków substytucyjnych, a ponadto w razie podjęcia prac nad nowelizacją przepisów warto rozważyć wprowadzenie obligatoryjnej okresowej weryfikacji istnienia podstaw do stosowania środka opiekuńczego.

Słowa kluczowe: petycja, ubezwłasnowolnienie

Doktor nauk prawnych, ekspert ds. legislacji Biura Analiz Sejmowych •

Kancelaria Sejmu, Biuro Analiz Sejmowych, Wydział Analiz Prawnych, Zespół Prawa

Prywatnego, WARSZAWA, POLSKA -

rafal.dubowski@sejm.gov.pl • https://orcid.org/0000000178524275

\section{Treść i cel petycji}

Petycja została wniesiona $\mathrm{w}$ interesie publicznym. Postuluje się w niej zniesienie instytucji ubezwłasnowolnienia całkowitego i częściowego, a ponadto wprowadzenie instytucji opieki asystencyjnej, zakładającej pozostawienie pod-

1 Opinia prawna na temat petycji nr BKSP-145-553/19 w sprawie zniesienia instytucji ubezwłasnowolnienia sporządzona 5 sierpnia 2019 r. na zlecenie przewodniczącego Komisji do Spraw Petycji; BAS-WAP 1209/19. 
opiecznemu pełnej zdolności do czynności prawnych i udzielanie mu wsparcia w podejmowaniu decyzji przez opiekuna. Poza tym proponuje się wprowadzenie opieki z reprezentacją równoległą. Zgodnie z postulatem przedstawionym w petycji osobie podlegającej tego rodzaju opiece przysługiwałaby zdolność do czynności prawnych, przy czym opiekun posiadałby prawo do reprezentowania podopiecznego w określonym zakresie. Oprócz tego w petycji zaproponowano ustanowienie obowiązku przebadania podopiecznego, co 3 lata, w celu stwierdzenia (bez)zasadności dalszego stosowania środka opiekuńczego. Ponadto postuluje się wprowadzenie regulacji umożliwiających unieważnienie czynności prawnej przez sąd w przypadku, gdy: 1) czynność prawna pociąga za sobą rażące pokrzywdzenie danej osoby lub jej najbliższych; 2) osoba ta w chwili dokonywania czynności nie była zdolna do pokierowania swoim postępowaniem oraz rozpoznania jego znaczenia.

\section{Czy petycja mieści się w zakresie zadań i kompetencji adresata petycji (art. 2 ust. 3 ustawy o petycjach)?}

Petycja dotyczy zmiany ustawy przez Sejm. Zgodnie z art. 95 ust. 1 Konstytucji RP władzę ustawodawczą w Rzeczypospolitej Polskiej sprawują Sejm i Senat. Natomiast stosownie do art. 118 ust. 1 Konstytucji inicjatywa ustawodawcza przysługuje m.in. posłom. Artykuł 32 ust. 2 regulaminu Sejmu w związku z art. 112 Konstytucji precyzuje, że poselskie projekty ustaw mogą być wnoszone przez komisje sejmowe lub grupę co najmniej 15 posłów podpisujących projekt. Uwzględniając powyższe, należy uznać, że petycja mieści się w zakresie zadań i kompetencji Sejmu.

\section{Wymogi formalne (art. 4 ust. 1 i 2 ustawy o petycjach)}

Petycja spełnia wymogi formalne określone w art. 4 ust. 1 i 2 ustawy o petycjach.

\section{Kwestie, które ekspert uznaje za istotne w związku z petycją}

\section{Ubezwłasnowolnienie w świetle obowiązujących regulacji}

W prawie polskim występują dwa rodzaje ubezwłasnowolnienia, tj. ubezwłasnowolnienie całkowite oraz częściowe. Zgodnie z art. $13 \$ 1$ k.c. ${ }^{2}$ : [o]soba, która ukończyła lat trzynaście, może być ubezwłasnowolniona całkowicie, jeżeli wskutek choroby psychicznej, niedorozwoju umysłowego albo innego rodzaju zaburzeń psychicznych, $w$ szczególności pijaństwa lub narkomanii, nie jest $w$ stanie kierować swym postę-

2 Ustawa z 23 kwietnia 1964 r. - Kodeks cywilny, t.j. Dz.U. 2019, poz. 1145; dalej: k.c. 
powaniem. Jak dodaje $\$ 2$ tego artykułu: [d]la ubezwłasnowolnionego całkowicie ustanawia się opiekę, chyba że pozostaje on jeszcze pod władza rodzicielską. Osoby ubezwłasnowolnione całkowicie nie mają zdolności do czynności prawnych tak samo jak osoby, które nie ukończyły lat trzynastu (art. 12 k.c.). Natomiast czynność prawna (a więc np. umowa) dokonana (zawarta) przez osobę, która nie ma zdolności do czynności prawnych, jest nieważna (art. $14 \$ 1$ k.c.). Jednakże gdy osoba niezdolna do czynności prawnych zawarła umowę należącą do umów powszechnie zawieranych $\mathrm{w}$ drobnych bieżących sprawach życia codziennego, umowa taka staje się ważna z chwilą jej wykonania, chyba że pociąga za sobą rażące pokrzywdzenie osoby niezdolnej do czynności prawnych (art. $14 \$ 2$ k.c.). Do tej kategorii umów należy zakwalifikować np. umowy sprzedaży artykułów spożywczych, środków higieny, papierniczych, przewozu środkami komunikacji miejskiej, uczestniczenia w imprezie kulturalnej, sportowej lub rozrywkowej, o ile nie mają dużej wartości ${ }^{3}$.

Jak stanowi art. $16 \$ 1$ k.c.: [o] soba petnoletnia może być ubezwłasnowolniona częściowo z powodu choroby psychicznej, niedorozwoju umysłowego albo innego rodzaju zaburzeń psychicznych, w szczególności pijaństwa lub narkomanii, jeżeli stan tej osoby nie uzasadnia ubezwłasnowolnienia całkowitego, lecz potrzebna jest pomoc do prowadzenia jej spraw. Dla osoby ubezwłasnowolnionej częściowo ustanawiana jest kuratela (art. $16 \$ 2$ k.c.). Osoby ubezwłasnowolnione częściowo mają ograniczoną zdolność do czynności prawnych tak samo jak małoletni, którzy ukończyli lat trzynaście (art. 15 k.c.). Do ważności czynności prawnej, przez którą osoba ograniczona w zdolności do czynności prawnych (a więc także osoba ubezwłasnowolniona częściowo) zaciąga zobowiązanie lub rozporządza swoim prawem, potrzebna jest zgoda jej przedstawiciela ustawowego (art. 17 k.c.). Jednak w przypadku, gdy umowa została zawarta przez osobę ograniczoną w zdolności do czynności prawnych bez wymaganej zgody przedstawiciela ustawowego, ważność umowy zależy od potwierdzenia umowy przez tego przedstawiciela (art. $18 \$ 1$ k.c.). Przy czym: [o] soba ograniczona $w$ zdolności do czynności prawnych może sama potwierdzić umowę po uzyskaniu petnej zdolności do czynności prawnych (art. $18 \$ 2$ k.c.). Ponadto osoba posiadająca ograniczoną zdolność do czynności prawnych może bez zgody przedstawiciela ustawowego zawierać umowy należące do umów powszechnie zawieranych $\mathrm{w}$ drobnych bieżących sprawach życia codziennego (art. 20 k.c.). Czynność prawna jednostronna, do której ustawa wymaga zgody przedstawiciela ustawowego, dokonana przez osobę ograniczoną w zdolności do czynności prawnych jest nieważna i inaczej niż umowa - nie może być konwalidowana przez wyrażenie zgody przez przedstawiciela ustawowego po dokonaniu czynności (art. 19 k.c.) $)^{4}$. Trzeba dodać, że osoba posiadająca ograniczoną zdolności do czynności prawnych może bez zgody przedstawiciela ustawowego rozporządzać swoim zarobkiem, chyba że

3 Zob. P. Księżak, Art. 14 [w:] Kodeks cywilny. Komentarz, red. K. Osajda, 2019, Legalis, pkt 3. 4 Zob. P. Księżak, Art. 19 [w:] Kodeks cywilny. Komentarz, red. K. Osajda, 2019, Legalis. 
sąd opiekuńczy z ważnych powodów inaczej postanowi (art. 21 k.c.). A ponadto gdy: przedstawiciel ustawowy osoby ograniczonej $w$ zdolności do czynności prawnych oddał jej określone przedmioty majątkowe do swobodnego użytku, osoba ta uzyskuje pełna zdolność $w$ zakresie czynności prawnych, które tych przedmiotów dotycza. Wyjątek stanowią czynności prawne, do których dokonania nie wystarcza według ustawy zgoda przedstawiciela ustawowego (art. 22 k.c.).

Ubezwłasnowolnienie i wiążące się z nim ograniczenie praw publicznych wywiera istotne skutki w sferze konstytucyjnych praw politycznych. Na przykład osoby ubezwłasnowolnione nie mają czynnego prawa wyborczego oraz prawa udziału w referendum (art. 62 ust. 2 Konstytucji), a tym samym nie mogą kandydować do Sejmu i Senatu (art. 99 Konstytucji), na urząd Prezydenta (art. 127 ust. 3 Konstytucji), nie mogą również korzystać z prawa powszechnej inicjatywy ustawodawczej (art. 118 ust. 2 Konstytucji) ${ }^{5}$.

Ubezwłasnowolnienie wywiera skutki także w zakresie stosunków prawnorodzinnych. Na przykład osoba ubezwłasnowolniona całkowicie nie może zawrzeć małżeństwa ${ }^{6}$. Ubezwłasnowolnienie całkowite wpływa na zdolność do wytoczenia powództwa o zaprzeczenie ojcostwa (art. 64 k.r.o.; art. $69 \$ 3$ k.r.o. w związku $\mathrm{z}$ art. 64 k.r.o.), macierzyństwa (art. $61^{13} \$ 3$; art. $61^{14} \S 2 \mathrm{w}$ związku z art. 64 k.r.o.) czy też ustalenie bezskuteczności uznania ojcostwa (art. $78 \$ 2$ w związku z art. 64 k.r.o.; art. $81 \S 3$ w związku z art. 64 k.r.o.).

Osoba ubezwłasnowolniona całkowicie nie może nawiązać stosunku pracy ${ }^{7}$. Natomiast osoba ubezwłasnowolniona częściowo - zgodnie z art. $22 \$ 3$ k.p. ${ }^{8}$ : może bez zgody przedstawiciela ustawowego nawiąać stosunek pracy oraz dokonywać czynności prawnych, które dotycza tego stosunku. Jednakże gdy stosunek pracy sprzeciwia się dobru tej osoby, przedstawiciel ustawowy za zezwoleniem sadu opiekuńczego może stosunek pracy rozwiązać.

Osoba ubezwłasnowolniona - co do zasady - nie może być krwiodawcą ${ }^{9}$ Za życia nie może ona być również dawcą komórek, tkanek lub narządów ${ }^{10}$. Ponad-

5 Zob. pkt III.1. uzasadnienia wyroku TK z 7 marca 2007 r., sygn. akt K 28/05, OTK-A ZU 2007, nr 3, poz. 24; R. Rybski, Konstytucyjny status osób ubezwłasnowolnionych, Warszawa 2015, s. 88.

6 Zob. art. $11 \$ 1$ ustawy z 25 lutego 1964 r. - Kodeks rodzinny i opiekuńczy, t.j. Dz.U. 2017, poz. 682, ze zm.; dalej: k.r.o.

7 Zob. postanowienie SN z 22 listopada 1979 r., sygn. akt III PZ 7/79, LEX nr 12619; G. Goździewicz, T. Zieliński, Art. 22 [w:] Kodeks pracy. Komentarz, red. L. Florek, 2017, LEX, pkt 14.

8 Ustawa z 26 czerwca 1974 r. - Kodeks pracy, t.j. Dz.U. 2019, poz. 1040.

9 Zob. art. 15 ust. 1 pkt 2 oraz art. 15 ust. 2 ustawy z 22 sierpnia 1997 r. o publicznej służbie krwi, t.j. Dz.U. 2019, poz. 1222; R. Rybski, Konstytucyjny status, op. cit., s. 105.

10 Zob. art. 12 ust. 1 pkt 7 ustawy z 1 lipca 2005 r. o pobieraniu, przechowywaniu i przeszczepianiu komórek, tkanek i narządów, t.j. Dz.U. 2019, poz. 1405; R. Rybski, Konstytucyjny status, op. cit., s. 105-106. 
to osoba ubezwłasnowolniona nie może samodzielnie zdecydować o tym, czy będzie dawcą po śmierci (decyzję w tym przedmiocie podejmuje przedstawiciel ustawowy) ${ }^{11}$. Zgodę na przeprowadzenie badania lub udzielenie innych świadczeń zdrowotnych w przypadku osoby całkowicie ubezwłasnowolnionej wyraża przedstawiciel ustawowy tej osoby ${ }^{12}$. Jednakże jeżeli osoba taka jest w stanie $\mathrm{z}$ rozeznaniem wypowiedzieć opinię w sprawie badania, konieczne jest ponadto uzyskanie zgody tej osoby ${ }^{13}$. Jeżeli jednak osoba ubezwłasnowolniona sprzeciwia się czynnościom medycznym, poza zgodą jej przedstawiciela ustawowego albo w przypadku niewyrażenia przez niego zgody wymagane jest zezwolenie sądu opiekuńczego $^{14}$.

Powyższa charakterystyka instytucji ubezwłasnowolnienia i jej skutków, choć skrótowa i tym samym niewyczerpująca, pokazuje, że ubezwłasnowolnienie związane jest z licznymi ograniczeniami dotykającymi wielu sfer życia, w szczególności prywatnego, gospodarczego i społecznego. Na tym tle trzeba stwierdzić, że zdolność do czynności prawnych i jej zakres jest istotnym wyznacznikiem wolności przysługującej jednostce. Ponadto zaprezentowana charakterystyka wskazuje, iż z uwagi na to, że ubezwłasnowolnienie wywołuje skutki prawne nie tylko w zakresie prawa cywilnego, ale również w obszarze innych gałęzi prawa, ewentualna reforma tej instytucji wymagałaby zmian systemowych.

\section{Ubezwłasnowolnienie w świetle konwencji o prawach osób niepełnosprawnych}

Trybunał Konstytucyjny stwierdził, że: osoby ubezwłasnowolnione powinny być zasadniczo traktowane jako osoby niepełnosprawne, którym należy się pomoc $w$ zabezpieczaniu egzystencji, przysposobieniu do pracy oraz komunikacji społecznej (art. 69 Konstytucji). Opieka nad osobami, którym zaburzenia psychiczne nie pozwalaja kierować swoim postępowaniem, zarówno ze strony innych osób, jak $i$ władz publicznych jest szczególnym aspektem wspomnianego $w$ preambule do Konstytucji obowiązku solidarności międzyludzkiej, jak również poszanowania i ochrony godności człowieka ${ }^{15}$.

11 Zob. art. 5 ust. 1-2 ustawy o pobieraniu, przechowywaniu i przeszczepianiu komórek, tkanek i narządów; R. Rybski, Konstytucyjny status, op. cit., s. 105-106.

12 Zob. art. 32 ust. 4 zdanie 1 ustawy z 5 grudnia 1996 r. o zawodach lekarza i lekarza dentysty, t.j. Dz.U. 2019, poz. 537, ze zm.; R. Rybski, Konstytucyjny status, op. cit., s. 106.

13 Zob. art. 32 ust. 4 zdanie drugie ustawy o zawodach lekarza i lekarza dentysty; R. Rybski, Konstytucyjny status, op. cit., s. 106.

14 Zob. art. 32 ust. 6 ustawy o zawodach lekarza i lekarza dentysty; R. Rybski, Konstytucyjny status, op. cit., s. 106.

15 Zob. pkt III.1. uzasadnienia wyroku TK z 7 marca 2007 r., sygn. akt K 28/05, OTK-A ZU 2007, nr 3, poz. 24. 
W dniu 25 sierpnia 2012 r. Prezydent RP ratyfikowal ${ }^{16}$ konwencję o prawach osób niepełnosprawnych, przyjętą 13 grudnia 2006 r. przez Zgromadzenie Ogólne Narodów Zjednoczonych w Nowym Jorku (Dz.U. 2012, poz. 1169). Zgodnie $\mathrm{z}$ art. 12 ust. 2 tej konwencji: Państwa Strony uznaja, że osoby niepełnosprawne maja zdolność prawna, na zasadzie równości z innymi osobami, we wszystkich aspektach życia. Natomiast ust. 3 tego artykułu zobowiązuje państwa strony do podjęcia odpowiednich środków w celu zapewnienia osobom niepełnosprawnym dostępu do wsparcia, którego mogą potrzebować przy korzystaniu ze zdolności prawnej. Z kolei, jak stanowi art. 12 ust. 4: Państwa Strony zagwarantują, że wszelkie środki związane z korzystaniem ze zdolności prawnej obejmować będa odpowiednie i skuteczne zabezpieczenia $w$ celu zapobiegania nadużyciom, zgodnie $z$ międzynarodowym prawem praw człowieka. Zabezpieczenia zapewnia, że środki związane z korzystaniem ze zdolności prawnej będa respektowały prawa, wole i preferencje osoby, będa wolne od konfliktu interesów i bezprawnych nacisków, będa proporcjonalne i dostosowane do sytuacji danej osoby, będa stosowane przez możliwie najkrótszy czas i będa podlegały regularnemu przeglądowi przez właściwe niezależne i bezstronne władze lub organ sadowy. Zabezpieczenia powinny być proporcjonalne do stopnia, w jakim takie środki wpływaja na prawa i interesy danej osoby.

Dostrzeżenie roli art. 12 konwencji o prawach osób niepełnosprawnych w kontekście ewentualnej reformy instytucji ubezwłasnowolnienia wymaga wyjaśnienia wątpliwości, które budzi występujące w nim określenie - zdolność prawna (legal capacity). Jak wskazuje się w piśmiennictwie prawniczym: [a]naliza założeń, celów oraz prac przygotowawczych prowadzi do wniosku, że celem art. $12 \mathrm{KPON}$ [Konwencji o prawach osób niepełnosprawnych - dopisek R.D.] było zagwarantowanie zdolności czynnej, a nie jedynie zdolności biernej (podmiotowości prawnej), której dotyczy bezpośrednio art. 12 ust. 1 KPON. Użycie sformułowania legal capacity wynika z braku ścisłego rozróżnienia pomiędzy zdolnościa prawna a zdolnościa do czynności prawnych w systemach prawnych państw common law ${ }^{17}$. Interpretację tę przyjął także Komitet ds. praw osób niepełno-

16 Ustawa o ratyfikacji Konwencji o prawach osób niepełnosprawnych, sporządzonej w Nowym Jorku 13 grudnia 2006 r., Dz.U. 2012, poz. 882; Convention on the Rights of Persons with Disabilities [w:] Status of treaties, https://treaties.un.org/Pages/ViewDetails. aspx?src=TREATY\&mtdsg_no=IV-15\&chapter=4\&lang=en [dostęp 31 lipca 2019 r.].

17 Cytat za: M. Domański, Ubezwłasnowolnienie w prawie polskim a wybrane standardy międzynarodowej ochrony praw człowieka, „Prawo w Działaniu. Sprawy Cywilne” 2014, 17, s. 30. Zob. P. Księżak, Art. 13 [w:] Kodeks cywilny. Komentarz, red. K. Osajda, 2019, Legalis, pkt 7, gdzie autor stwierdza: [w] polskiej wersji językowej niewatpliwie błędnie w art. 12 używa się terminu „zdolność prawna”, mimo że zarówno z przebiegu prac nad PrawNiepK, treści oryginalnej angielskiej wersji językowej (legal capacity), jak $i$ kontekstu wynika, że chodzi bardziej o zdolność do czynności prawnych. Tłumaczenie wypacza zatem sens przepisu w sposób niekorzystny dla osób z niepetnosprawnością. A ponadto zob. M. Balwicka-Szczyrba, A. Sylwestrzak, Instytucja ubezwłasnowolnienia 
sprawnych (ustanowiony na podstawie art. 34 konwencji o prawach osób niepełnosprawnych) w komentarzu do przepisów tej konwencji ${ }^{18}$. Podzielił ją również polski Sąd Najwyższy, stwierdzając w uzasadnieniu uchwały z 21 grudnia 2017 r.: [i]nterpretacja art. 12 Konwencji, prowadzona $z$ uwzględnieniem jej obcojęzycznych tekstów oraz oficjalnego komentarza do tego postanowienia (por. General comment No. 1 (2014), pkt 12, Committee on the Rights of Persons with Disabilities, (http://www.ohchr.org/EN/HRBodies/CRPD/Pages/GC.aspx)), prowadzi przy tym do wniosku, że postanowienie to dotyczy nie tylko zdolności prawnej, lecz także zdolności do czynności prawnych (legal capacity, capacité juridique, Rechts- und Handlungsfähigkeit). Taki sam wniosek wynika z polskiego tłumaczenia Konwencji opublikowanego w Dzienniku Urzędowym Unii Europejskiej, w którym mowa jest $w$ art. 12 ust. 2-4 o zdolności prawnej i zdolności do czynności prawnych, mając na względzie, że Konwencja, po jej zatwierdzeniu decyzja Rady 2010/48/WE z dnia 26 listopada 2009 r. (Dz.Urz. UE z 2010 r., L 23, s. 35), wiąze Rzeczpospolita Polska także jako integralny element prawa unijnego (por. wyrok Trybunału Sprawiedliwości Unii Europejskiej z dnia 11 kwietnia 2013 r., C-335/11 i C-337/11 (sprawy połaczone), HK Danmark przeciwko Dansk almennyttigt Boligselskab i HK Danmark przeciwko Dansk Arbejdsgiverforening, ECLI:EU:C:2013:222) ${ }^{19}$.

W związku z tym, że art. 12 ust. 4 konwencji o prawach osób niepełnosprawnych dotyczy także zdolności do czynności prawnych, trzeba stwierdzić, że regulacje dotyczące ubezwłasnowolnienia - zgodnie z tym przepisem - powinny:

- respektować prawa, wolę i preferencje osoby,

- eliminować konflikty interesów i bezprawne naciski,

- być proporcjonalne i dostosowane do sytuacji danej osoby,

w perspektywie unormowań Konstytucji RP oraz Konwencji ONZ o prawach osób niepełnosprawnych, „Gdańskie Studia Prawnicze” 2018, t. XL, s. 152, gdzie autorki wskazują, że: [u] żyte $w$ tym przepisie pojęcie legal capacity w polskim przekładzie zostało sformułowane, wedtug dosłownego tłumaczenia, jako „zdolność prawna”, co w doktrynie spotkało się z uzasadniona krytyką. Wywodzi się bowiem, że określenie to, biorac pod uwage petna treść art. 12 Konwencji ONZ, odnosi się nie tylko do płaszczyzny statycznej podmiotowości, obejmującej przysługiwanie praw, lecz także płaszczyzny dynamicznej - skoro $w$ dalszej części przepisu mowa jest o korzystaniu ze zdolności prawnej. Zamysł tkwiący u podstaw unormowań Konwencji ONZ lepiej odzwierciedlałoby więc określenie „zdolność w sferze prawa” obejmujące zarówno zdolność prawna, jak i zdolność do czynności prawnych. Podobnie na temat wykładni art. 12 konwencji zob. M. Szeroczyńska, Ubezwłasnowolnienie $i$ alternatywne formy pomocy $w$ realizowaniu zdolności do czynności prawnych osób z niepełnosprawnością intelektualną, w regulacjach międzynarodowych oraz w prawie obcym, na przykładzie Estonii, Niemiec, Szwecji, Wielkiej Brytanii i Kanady (stanu Manitoba) [w:] Jeśli nie ubezwłasnowolnienie, to co? Prawne formy wsparcia osób z niepełnosprawnością intelektualną, red. K. Kędziora, Warszawa 2012, s. 24-26.

18 Zob. M. Domański, Ubezwłasnowolnienie, op. cit., s. 31-33.

19 Uchwała SN z 21 grudnia 2017 r., sygn. akt III CZP 66/17, Legalis nr 1697215. 
- być stosowane przez możliwie najkrótszy czas,

- podlegać regularnemu przeglądowi przez właściwe niezależne i bezstronne władze lub organ sądowy.

Oceniając polskie regulacje w świetle wymogów konwencji, Małgorzata Balwicka-Szczyrba oraz Anna Sylwestrzak wskazały, że: [b]ez watpienia polska instytucja ubezwłasnowolnienia nie spełnia powyższych wymogów, choćby dlatego, że z uwagi na nieelastyczna formułę dwóch postaci ubezwłasnowolnienia nie jest dostosowana do sytuacji danej osoby [...], jak również dlatego, że zakres opieki nie uwzględnia aktywizacji osoby ubezwłasnowolnionej ${ }^{20}$. Z kolei M. Domański podniósł, że: polski system prawny oparty na instytucji ubezwłasnowolnienia całkowitego nie mieści się w modelu konwencyjnym, nawet przy bardziej „ostrożnej” jego interpretacji. Wątpliwości budzi z tego punktu widzenia również ubezwłasnowolnienie częściowe. Można doszukiwać się w tej instytucji pewnych elementów „wsparcia”, jednak orzeczenie ogranicza istotnie zdolność do czynności prawnych, może zostać ustanowione wbrew woli osoby niepetnosprawnej, ma charakter bezterminowy $i$, co chyba najistotniejsze, kurator powołany do reprezentowania osoby ubezwłasnowolnionej może działać jako przedstawiciel ustawowy, dokonując czynności z bezpośrednim skutkiem dla ubezwłasnowolnionego w zakresie takim, jak opiekun osoby ubezwłasnowolnionej całkowicie [...] nie ma przy tym obowiązku respektowania stanowiska ubezwłasnowolnionego ${ }^{21}$. Podobne oceny dotyczące niezgodności instytucji ubezwłasnowolnienia $\mathrm{z}$ konwencją przedstawiają także inni autorzy ${ }^{22}$.

W dniu 25 września 2012 r. zostało złożone oświadczenie rządowe w sprawie mocy obowiązującej konwencji o prawach osób niepełnosprawnych, sporządzonej w Nowym Jorku 13 grudnia 2006 r. (Dz.U. 2012, poz. 1170), w którym stwierdzono, że: Rzeczpospolita Polska oświadcza, że interpretuje art. 12 konwencji w sposób zezwalajacy na stosowanie ubezwłasnowolnienia, w okolicznościach $i$ w sposób określony w prawie krajowym, jako środka, o którym mowa w art. 12 ust. 4, w sytuacji, gdy wskutek choroby psychicznej, niedorozwoju umysłowego lub innego rodzaju zaburzeń psychicznych osoba nie jest $w$ stanie kierować swoim postępowaniem. Niemniej w literaturze prawniczej wskazuje się, że wbrew nazwie oświadczenie to należy uznawać za zastrzeżenie w rozumieniu art. 2 ust. 1 lit. d konwencji wiedeńskiej o prawie traktatów z 23 maja 1969 r. (Dz.U. 1990, nr 74, poz. 439), i to za zastrzeżenie niedopuszczalne, ze względu na to, iż jest ono

20 M. Balwicka-Szczyrba, A. Sylwestrzak, Instytucja ubezwłasnowolnienia, op. cit., s. 153.

Zob. M. Domański, Ubezwłasnowolnienie, op. cit., s. 44-45.

22 Zob. P. Księżak, Art. 13, op. cit., pkt 7; D. Mróz, Krytycznie wobec postulatu zniesienia ubezwłasnowolnienia $w$ kontekście harmonizacji polskiego prawa cywilnego z Konwencja ONZ o prawach osób niepetnosprawnych, „Acta Iuris Stetinensis” 2018, nr 4, s. 16-17; M. Zima-Parjaszewska, Artykuł 12 Konwencji ONZ o prawach osób z niepetnosprawnościami a ubezwłasnowolnienie w Polsce, „Studia Prawnicze” 2013, nr 2, s. 99-100; R. Rybski, Konstytucyjny status, op. cit., s. 152. 
sprzeczne z celem konwencji (art. 19 lit. c konwencji wiedeńskiej o prawie traktatów oraz art. 46 konwencji o prawach osób niepełnosprawnych) ${ }^{23}$. W konsekwencji przyjmuje się, że Polska jest związana w całości art. 12 konwencji o prawach osób niepełnosprawnych ${ }^{24}$.

Mając powyższe na uwadze, trzeba wskazać, że reforma instytucji ubezwłasnowolnienia jest pożądana ze względu na potrzebę wypełnienia zobowiązań międzynarodowych. Tym samym zasadne jest postawienie pytania, o kierunki ewentualnych zmian.

\section{Modele prawne ochrony osób dorosłych}

W piśmiennictwie prawniczym wartościowe typologie środków ochrony dorosłych przedstawił L. Kociucki ${ }^{25}$. W ślad za nim ze względu na „źródło” danego środka można wyróżnić:

- środki władcze ustanawiane na podstawie orzeczenia sądu (np. orzeczenie o ubezwłasnowolnieniu, a następnie ustanowieniu opieki),

- środki ochrony przedsiębrane przez dorosłego we własnym zakresie (np. pełnomocnictwo opiekuńcze),

- środki ochrony skuteczne z mocy prawa (np. instytucje prawne umocowujące bliskich do reprezentacji podopiecznego bez konieczności wydawania orzeczenia przez sąd $)^{26}$.

Ze względu na zakres ochrony:

- środki pełne (obejmujące wszystkie sprawy podopiecznego),

- zakresowe (obejmujące określony zakres spraw),

- środki ad casum (dotyczące jednej lub kilku konkretnych spraw, dla których środek jest ustanawiany ${ }^{27}$.

Ze względu na czas, na jaki są ustanawiane:

- środki na czas nieokreślony,

- środki na czas określony,

- środki ad casum ustanawiane dla potrzeb jednej sprawy ${ }^{28}$.

23 Zob. P. Księżak, Art. 13, op. cit., pkt 7; M. Domański, Ubezwłasnowolnienie, op. cit., s. 38-41. Por. M. Balwicka-Szczyrba, A. Sylwestrzak, Instytucja ubezwłasnowolnienia, op. cit., s. 153; M. Zima-Parjaszewska, Artykut 12 Konwencji ONZ o prawach osób z niepetnosprawnościami, op. cit., s. 97-98.

24 Zob. M. Domański, Ubezwłasnowolnienie, op. cit., s. 41; P. Księżak, Art. 13, op. cit., pkt 7-8.

25 L. Kociucki, Niektóre problemy nowelizacji polskiego prawa o ubezwłasnowolnieniu, „Studia Prawnicze” 2013, nr 2, s. 111-112.

26 Ibidem.

27 Ibidem, s. 112.

28 Ibidem. 
Natomiast ze względu na rodzaj pieczy można wyodrębnić:

- środki substytucyjne (osoba sprawująca pieczę podejmuje czynności zamiast podopiecznego),

- środki asystencyjne (opiekun działa obok podopiecznego) ${ }^{29}$.

Ponadto środki ochrony dorosłych można podzielić (według zakresu swobody, którą dysponuje organ orzekający o ich zastosowaniu lub osoba podejmująca decyzję o skorzystaniu z nich) na tzw. środki „szyte na miarę” oraz środki, których treść jest ściśle zdefiniowana w ustawie ${ }^{30}$.

Przedstawione typologie pokazują, że ustawodawca dysponuje szerokim wachlarzem środków, za pomocą których może zapewnić ochronę osobom dorosłym, które z uwagi na różnego rodzaju zaburzenia psychiczne nie są w stanie kierować swoim postępowaniem. Możliwych rozwiązań jest wiele, zwłaszcza jeśli weźmiemy pod uwagę, że konkretne środki ochrony osób dorosłych łączą cechy poszczególnych typów. Konstrukcja prawna tych środków - jak się wydaje - powinna stanowić kompromis między potrzebą poszanowania godności i wolności osoby, która ze względu na różnego rodzaju zaburzenia psychiczne nie jest w stanie kierować swoim postępowaniem, a potrzebą ochrony interesów tej osoby, jej rodziny, bliskich oraz innych uczestników obrotu prawnego.

\section{Ubezwłasnowolnienie w świetle projektu założeń Komisji Kodyfikacyjnej Prawa Cywilnego}

Zagadnienie reformy instytucji ubezwłasnowolnienia było przedmiotem prac prowadzonych przez Komisję Kodyfikacyjną Prawa Cywilnego. Prace nad projektem założeń nowelizacji Kodeksu cywilnego, Kodeksu postępowania cywilnego, Kodeksu rodzinnego i opiekuńczego i innych ustaw Komisja zakończyła 22 marca 2013 r. ${ }^{31}$. Projekt założeń został przyjęty przez Radę Ministrów 10 marca 2015 r. $^{32}$. W projekcie tym zaproponowano wyeliminowanie odrębnych instytucji: ubezwłasnowolnienia częściowego i całkowitego, opieki nad ubezwłasnowolnionymi całkowicie, kurateli nad ubezwłasnowolnionymi częściowo, kurateli dla osoby niepełnosprawnej i zastąpienie ich instytucją opieki o zróżnicowanym zakresie i formie, dostosowanym do sytuacji poszczególnych osób ${ }^{33}$. Zgodnie

29 Ibidem.

30 Ibidem.

31 Komisja Kodyfikacyjna Prawa Cywilnego, https://arch-bip.ms.gov.pl/pl/dzialalnosc/ komisje-kodyfikacyjne/komisja-kodyfikacyjna-prawa-cywilnego/ [dostęp 31 lipca 2019 r.]. Zob. D. Mróz, Krytycznie wobec postulatu, op. cit., s. 18.

32 Zob. protokół ustaleń nr 10/2015 posiedzenia Rady Ministrów w dniu 10 marca 2015 r., https://legislacja.rcl.gov.pl/docs//1/208000/208041/208045/dokument165691. pdf [dostęp 31 lipca 2019 r.]; zob. D. Mróz, Krytycznie wobec postulatu, op. cit., s. 18.

33 Test regulacyjny do projektu założeń projektu ustawy o zmianie ustawy - Kodeks cywilny, ustawy - Kodeks rodzinny i opiekuńczy, ustawy - Kodeks postępowania cywil- 
z projektem założeń, orzekając o ustanowieniu opieki, sąd określałby zakres zadań opiekuna, przy czym mógłby, stosownie do potrzeb osoby korzystającej z ochrony, powierzyć mu określoną rolę w procesie realizacji zdolności do czynności prawnych przez podopiecznego. Możliwe to byłoby w jednej albo kilku $\mathrm{z}$ następujących form:

- opieka asystencyjna, pozostawiająca osobie korzystającej z ochrony pełną zdolność do czynności prawnych, a polegająca na udzielaniu podopiecznemu wsparcia w podejmowaniu decyzji,

- opieka z reprezentacją „równoległą”, pozostawiająca osobie korzystającej z ochrony zdolność do czynności prawnych, a jednocześnie nadająca opiekunowi upoważnienie do reprezentowania podopiecznego w oznaczonym zakresie,

- opieka z kompetencją do współdecydowania, polegająca na zastrzeżeniu zgody lub potwierdzenia opiekuna dla ważności oznaczonych rodzajów czynności prawnych osoby korzystającej z ochrony,

- opieka połączona z umocowaniem do wyłącznego zastępstwa, w której upoważnienie do podejmowania czynności prawnych w oznaczonym w orzeczeniu zakresie miałby tylko opiekun, a nie miałaby go osoba $\mathrm{z}$ niepełnosprawnością psychiczną ${ }^{34}$.

Decyzja o wyborze jednej albo kilku wymienionych form opieki (dla różnych zakresów czynności prawnych) należałaby do sądu ${ }^{35}$.

W projekcie założeń zaproponowano wprowadzenie tzw. pełnomocnictwa opiekuńczego. Jego sens polega na tym, że osoba dorosła i sprawna psychicznie może ustanowić pełnomocnika, który byłby upoważniony do dokonywania w jej imieniu określonych czynności, w tym także o charakterze osobistym, gdyby mocodawca doznał w przyszłości zaburzeń psychicznych ${ }^{36}$.

Z uwagi na rozwiązanie Komisji Kodyfikacyjnej Prawa Cywilnego z dniem 17 grudnia 2015 r. prace nad projektem zostały przerwane ${ }^{37}$.

nego, ustawy o wspieraniu rodziny i systemie pieczy zastępczej oraz niektórych innych ustaw, https://legislacja.rcl.gov.pl/docs//1/208000/208001/208002/dokument127276. pdf [dostęp 31 lipca 2019 r.], s. 1; projekt założeń projektu ustawy o zmianie ustawy - Kodeks cywilny, ustawy - Kodeks rodzinny i opiekuńczy, ustawy - Kodeks postępowania cywilnego, ustawy o wspieraniu rodziny i systemie pieczy zastępczej oraz niektórych innych ustaw, https://legislacja.rcl.gov.pl/docs//1/208000/208001/208002/ dokument104528.pdf [dostęp 31 lipca 2019 r.], s. 9; zob. D. Mróz, Krytycznie wobec postulatu, op. cit., s. 18-20.

34 Projekt założeń, op. cit., s. 11. Zob. D. Mróz, Krytycznie wobec postulatu, op. cit., s. 18-20.

35 Projekt założeń, op. cit., s. 11.

36 Projekt założeń, op. cit., s. 15; zob. D. Mróz, Krytycznie wobec postulatu, op. cit., s. 20; M. Balwicka-Szczyrba, A. Sylwestrzak, Instytucja ubezwłasnowolnienia, op. cit., s. 166.

37 Komisja Kodyfikacyjna Prawa Cywilnego, https://arch-bip.ms.gov.pl/pl/dzialalnosc/ komisje-kodyfikacyjne/komisja-kodyfikacyjna-prawa-cywilnego/ [dostęp 31 lipca 


\section{Rozwiązania proponowane w petycji}

Można zauważyć, że postulaty przedstawione w petycji są częściowo zbliżone do założeń przyjętych przez Komisję Kodyfikacyjną Prawa Cywilnego. W odróżnieniu jednak od Komisji, autorzy petycji nie proponują wprowadzenia opieki z kompetencją do współdecydowania oraz opieki połączonej z umocowaniem do wyłącznego zastępstwa, lecz wyłącznie opiekę asystencyjną oraz opiekę z reprezentacją „równoległą”. Wydaje się jednak, że rozwiązania proponowane w petycji mogą niedostatecznie chronić interesy osoby objętej opieką, jej rodziny, bliskich oraz innych uczestników obrotu prawnego, ponieważ żaden z zaproponowanych środków nie zapobiega np. zaciąganiu niekorzystnych zobowiązań lub dokonywaniu takich rozporządzeń. W razie sporu w każdym wypadku osoba, która ma w tym interes prawny, musiałaby - powołując się na art. 82 k.c. - na podstawie różnych środków dowodowych wykazać, że oświadczenie zostało złożone w stanie wyłączającym świadome albo swobodne powzięcie decyzji i wyrażenie woli, a z tego powodu oświadczenie to, jak również konstytuowana przez nie czynność prawna - są nieważne z mocy prawa. Natomiast jeśli opiekunowi przysługiwałoby uprawnienie do wyłącznej reprezentacji albo uprawnienie do współdecydowania, o nieważności czynności prawnej przesądzałaby już sama treść wyroku sądu o ustanowieniu opiekuna (a w wypadku opieki z uprawnieniem do współdecydowania także brak zgody opiekuna). Trudności tych nie eliminowałoby także wprowadzenie proponowanych w petycji regulacji umożliwiających unieważnienie czynności prawnej przez sąd wówczas, gdy: a) czynność prawna pociąga za sobą rażące pokrzywdzenie danej osoby lub jej najbliższych; b) osoba ta w chwili dokonywania czynności nie była zdolna do pokierowania swoim postępowaniem oraz rozpoznania jego znaczenia. Dlatego wydaje się, że w niektórych przypadkach - oprócz zaproponowanych w petycji środków opiekuńczych - ustawodawstwo powinno przewidywać możliwość zastosowania środków substytucyjnych (polegających na tym, że osoba sprawująca pieczę podejmuje czynności zamiast podopiecznego lub wraz z nim, współdecydując o jego sprawach).

\section{Wnioski}

Reforma instytucji ubezwłasnowolnienia jest pożądana ze względu na potrzebę wypełnienia zobowiązań międzynarodowych. Prace nad zmianami były podejmowane przez Komisję Kodyfikacyjną Prawa Cywilnego, lecz wraz z jej rozwiązaniem zostały przerwane. Zastąpienie ubezwłasnowolnienia opieką asystencyjną oraz opieką z reprezentacją „równoległą” (tak jak zaproponowano w petycji) może być rozwiązaniem niedostatecznie chroniącym interesy osoby objętej opie-

2019 r.]; D. Mróz, Krytycznie wobec postulatu, op. cit., s. 20; M. Balwicka-Szczyrba, A. Sylwestrzak, Instytucja ubezwłasnowolnienia, op. cit., s. 166. 
ką, jej rodziny, bliskich oraz innych uczestników obrotu prawnego. Wydaje się, że w niektórych wypadkach - oprócz tych środków - ustawodawstwo powinno przewidywać możliwość zastosowania środków substytucyjnych (polegających na tym, że osoba sprawująca pieczę podejmuje czynności zamiast podopiecznego lub wraz z nim, współdecydując o jego sprawach). W razie podjęcia prac nad nowelizacją niewątpliwie warto byłoby rozważyć wprowadzenie obligatoryjnej okresowej weryfikacji istnienia podstaw do stosowania środka opiekuńczego. Jednak zakres tego obowiązku i sposób jego realizacji należałoby określić dopiero po wyborze środków opiekuńczych i ustaleniu materialnoprawnych przesłanek ich stosowania. Z uwagi na to, że ubezwłasnowolnienie wywołuje skutki prawne nie tylko w zakresie prawa cywilnego, ale również w obszarze innych gałęzi prawa, realizacja postulatów przedstawionych w petycji wymagałaby zmian systemowych.

\section{Bibliografia}

Balwicka-Szczyrba M., Sylwestrzak A., Instytucja ubezwłasnowolnienia w perspektywie unormowań Konstytucji RP oraz Konwencji ONZ o prawach osób niepełnosprawnych, „Gdańskie Studia Prawnicze” 2018, t. XL.

Domański M., Ubezwłasnowolnienie $w$ prawie polskim a wybrane standardy międzynarodowej ochrony praw człowieka, „Prawo w Działaniu. Sprawy Cywilne” 2014, nr 17.

Goździewicz G., Zieliński T., Art. 22 [w:] Kodeks pracy. Komentarz, red. L. Florek, 2017, LEX.

Kociucki L., Niektóre problemy nowelizacji polskiego prawa o ubezwłasnowolnieniu, „Studia Prawnicze" 2013, nr 2.

Księżak P., Art. 13, art. 14, art. 19 [w:] Kodeks cywilny. Komentarz, red. K. Osajda, 2019, Legalis.

Mróz D., Krytycznie wobec postulatu zniesienia ubezwłasnowolnienia w kontekście harmonizacji polskiego prawa cywilnego z Konwencja ONZ o prawach osób niepełnosprawnych, „Acta Iuris Stetinensis” 2018 nr 4, https://doi.org/10.18276/ais.2018.24-01.

Rybski R., Konstytucyjny status osób ubezwłasnowolnionych, Warszawa 2015.

Szeroczyńska M., Ubezwłasnowolnienie i alternatywne formy pomocy $w$ realizowaniu zdolności do czynności prawnych osób z niepetnosprawnościa intelektualna, w regulacjach międzynarodowych oraz w prawie obcym, na przykładzie Estonii, Niemiec, Szwecji, Wielkiej Brytanii i Kanady (stanu Manitoba) [w:] Jeśli nie ubezwłasnowolnienie, to co? Prawne formy wsparcia osób z niepetnosprawnościq intelektualną, red. K. Kędziora, Warszawa 2012.

Zima-Parjaszewska M., Artykuł 12 Konwencji ONZ o prawach osób z niepełnosprawnościami a ubezwłasnowolnienie w Polsce, „Studia Prawnicze” 2013, nr 2. 